\title{
The Medieval Town of Kazakhstan
}

\author{
Saiden Zholdasbaev ${ }^{1} \&$ Moldir Aldabergenova ${ }^{1}$ \\ ${ }^{1}$ Faculty of History and Pedagogy, A. Yasawi International Kazakh-Turkish University, Turkestan, 161200, \\ Kazakhstan
}

Correspondence: Moldir Aldabergenova, Faculty of History and Pedagogy, A. Yasawi International Kazakh-Turkish University, Turkestan, 161200, Kazakhstan. Tel: 7-702-370-3047. E-mail:_mol-nur_an@mail.ru

\author{
Received: February 28, 2013 Accepted: April 5, 2013 Online Published: April 27, 2013 \\ doi:10.5539/ass.v9n5p73 \\ URL: http://dx.doi.org/10.5539/ass.v9n5p73
}

\begin{abstract}
Medieval towns and settlements on the territory of Kazakhstan is amounted by hundreds and most of them remained in the form of yellow hills that require a deep study by archaeologists. Of course one needs to consider that not every city became the political center for five centuries of a State. Syganak in this area is isolated from other territories and its archaeological study may decide to Kazakhstan's history the most key issues at the moment.
\end{abstract}

Keywords: medieval Kazakhstan, commercial and political center, medieval town, Syganak

\section{Introduction}

Speaking about trade relations in South Kazakhstan, one can specify two areas on which they were performed. On one hand there was an intensive exchange of goods in the markets of cities lying "along the caravan route from Islamic world to China", it was a number of cities, including Syganak which was a capital of the Kipchak Khanate in XI-XIII centuries, became a center of White (Blue) Horde in XIV-XV centuries, and became a political center of the Kazakh Khanate in XV-XVI centuries. On the other hand in the cities there was a great sale of the products coming from different parts of Asia, and to some extent from Eastern Europe: the slaves, grain, leather, cotton fabrics, woolen fabrics, silk, etc. It would be wrong to say that these cities located on the given direction were founded only due the need for cultural exchange of goods between the strip and the steppe. The main reason for their appearance is different. It has long been held that a caravan road in the most stopping points attracted the barter force from the nearest areas. The market development takes place in all these areas, many of which turn into real city.

\section{Main Part}

\subsection{Mentioning of the City in the Written Sources}

To the cities of southern Kazakhstan, which were related to Turkestan region (province), the city of Syganak was belonging, which is firstly mentioned in the sources of X-XI centuries. By Mahmud of Kashgar, in his "Collection of Turkish languages," we meet the outline that Sygnak was one of Oguz cities, located close to the site of the Samanid state settlements (Kashkari, 1997). Here we have an evidence of not only undoubted existence of the city, but also see that in X and in the beginning of XI century the roamed Guzas, like other Turkic nomads, lived in the vast expanses of the steppes of the lower flow of Syr Darya to the lower Kama, already had cities.

Academician V.V. Barthold who wrote many books about the history of Kazakhstan and Central Asia states that Sugnak (or Sygnak) is not mentioned by Arab geographers, but in respect of it, a city mentioned by a anonymous Persian geographer in X (so-called Tumanian manuscript) might be identical to the mentioned city of Sunah", a small town in the Faraba area (Otrar), very rich one; good bows there are taken to different places from there. Syganak had relations not only with steppe and the cities of Maurya but also with Khorezm (Barthold, 1963, p. 560). In the middle of the XII century in the sources appear the news about Sygnak possession of Kipchak (Kipchak possession or differently Deshti Kipchak, that is "Kipchak steppe", was extended to the huge areas from the spurs of Altai Mountains in the east to the Carpathian slopes in the West), located in close proximity to Khorezm and therefore become a real object of their claims, as Khorezm didn't allow the existence of strong political opponent on its northern and north-eastern borders (Ahinzhanov, 1989). In order to create a large independent state, Khorezm had to struggle not only with the West, but also with nomads from the steppe 
located to North and to the East. To strengthen its position inside the area it had to acquire a number of fortified urban settlements in the area of Syr Darya. On this basis occurs a desire of Khorezmshah Atsyz (leader of the empire Khorezmshah in 1128-1156) to go with the army to the land of Kipchak, where the capital was Syganak. In XIII century, like many cities along the middle flow of Syr Darya the city of Syganak was destroyed by the Mongols (led by Genghis Khan) and its population was killed. I.P. Petrushevskiy eloquently writes about it, based on the message Juvayni (who lived in XII-XIII centuries), an author of the book "Tarikh-Zhahangush (History of the worlds' leaders)": "Otrar fell in February 1220. Meanwhile a squad of Jochi, which is the eldest son of Genghis Khan, who during the winter of 1219/20 has occupied one city after another on the lower flow of Syr Darya. He was accompanied by local merchants, and Hasan- Khoja and Ali-Khoja, which before the war, have accessed to the service of Mongols. Hasan-Khoja was sent to Syganak in order to persuade people to give up, but the "villains, vulgars and vagabonds slew the traitor and demonstrated to the enemy a brave resistance. After seven days of continuous combat Syganak was taken, the population was cut entirely" (Petrushevskiy, 1977)

An above given information, despite of their paucity, give the opportunity to present in general an economic and political nature Syganak. Having emerged as the market, on the border of steppes and cultural strip, Syganak was primarily a trading center. The defeat in 1219 ended the first period in the history of Syganak. In the second half of the XIII century it is only once a name of Syganak met in the book of Kirakos - Armenian historian of the XIII century. Describing one of the interesting route of travel to the headquarters of Mongol to Mangu Khan, done by Armenian king Getum (Hetum) in 1254, Kirakos detail lists the settlements, where the Armenian king was on his way back, especially in the area from Bishbalyk to Otrar (medieval city). An interesting route for us in this place is where it says that when reaching Talas, Getum turned to the north-west to the lower flow of the Syr Darya, which is formed at the confluence of the rivers Naryn and Karadarya in the eastern part of the Fergana Valley and since ancient times there were urban settlements along the river. After going somewhere through Karatau mountains, he had his "Szungah, that is a mountain Harchuh (Karatau mountain, Montenegro), then arrived to Onzan, then to "Sauran, which was very great", and through a number of stops to Otrar" (Gandzaketsi, 1976). But according to the content of this source, we understand that these records do not relate to an existing city. Here the settlements are taken into account, where the cities were located. But regarding the other written sources related to XIV century, more precisely to 1328 , the city's name is nowhere mentioned. Despite these destructive actions of the Mongols, a part of the towns in the region was revived including Syganak, and their economic status was stabilized in the second half of XIII century, when several Uluses were formed, as illustrated, except the written sources, in archaeological research. Part of the territory of South Kazakhstan and Central Asia became a part of Chagatai Ulus, belonging to the second son of Genghis Khan. Jochi Ulus was emerged after completion of campaign of Mongol feudal in the West under the leadership of the son of Jochi Khan Batu. White Horde, according to some researchers, is the first state in the formation of modern Kazakhstan in post-Mongol period, where Horde Ichen and his descendants ruled from the middle of XIII up to the first quarter of the XV century, inclusively (some sources say that he is the eldest son of Jochi, in some others - youngest son, as "Ichen" means "lord-master" this name was given to the Mongols youngest son) (Mingulov, 1981). According to other researchers, the time of the White and Blue Horde nearly equal in age of being of Jochi Ulus, and they are dated to the time before the Western campaign, and, therefore, must be dated by earlier time than the middle of the XIII century. White Horde failed along with the Golden Horde and the Blue Horde ceased to exist after the first successors of Horde Ichena, long before the XV century (Yudin, 1983). Without going in the details of the discussion regarding the question on the time of existence and location of the White Horde and Blue Horde, we will pay our attention to the fact, that the capital of the given state units was the city Syganak, which by some researchers, was a capital of White Horde, and by others a Blue Horde capital. For studying the history of Syganak, along with the written sources, an important role play also numismatic materials showing in details the inner, trade-economic, monetary system and international relations that have taken place in the city at different leaders succeeded each other over periods of time. For example, it is know that Syganak is actively involved in providing funds Pre-Syrdarya region, releasing silver and copper coins, which are found in coin complexes of different cities of Turkestan and the Volga region. And this is confirmed by archaeological evidence. For example, at excavation of Otrar, made in 1971-1977, 10 the copper coins of Juchi have been found, where 3 of them belong to Syganak. The catalog of coins from the town of Otrar Tobe 3 coins of Juchi coinage were defined within 1979-1985, one of them belongs to the release Syganak time, the year was not defined (Pishchulina, 1969). The catalog of coins from the excavations and collections on Otrar Tobe (Otrar the medieval city name, tobe - in Kazakh means hill) for 1976-1985 also contains of Syganak stamp with the lost date ( 3 copies). The same exemplar exists in the catalogue of coins obtained from the excavations of Kuyruktobe (medieval city, located near the medieval town of Otrar) for 1980-1984, and it has no difference according to the 
type and appearance from the coins found in Otrar in 1978. The hoard under the number 197, found in the village of Sosnovka in Kazan district of the Russian Federation in 1911, consisting of 925 silver coins, has a stamp of Sygnak dated by the years 1375-76. Near Tashkent in 1931, the treasure with utensils of counterfeiter, along with fake copper coins, with a small admixture of silver, consisting of Juchi, Chagatai and Timurid stamps of XIV century was discovered. As a part of the treasure there are Sygnak coins ( 8 copies). The Sygnak stamp is also in the rich numismatic complex, obtained by archaeologists from the settlement Shed, located in the western part of Kazakhstan. During the in-situ investigations, conducted by the West Kazakhstan expedition of the Institute of Archaeology named after A. H. Margulan in 1996-2000, but without final definitions and release information, the coins were found (Burnasheva, 2006).

In the "Anonym of Iskander" it is said, that Khan Erzen (fifth descendant of Horde Ichena) died in 745 of Hijra (countries where Islam religion was used in this system of chronology), which is clearly not a true, since on the coins of his son Mubarak-Khoja, found in Syganak, a year 728 of Hijra is stamped on them. The Hermitage (this museum is located in St. Petersburg, Russia), there are five coins stamped in Syganak on behalf of Mubarek Hodge. All coins were viewed, assessed by the author of the article "The ruins of Sygnak, A.Yu.Yakubovskij". The article says that the names of Mubarak-Khoja and Syganak are clearly mentioned there. However, only two of them are clearly given of 768 Hijra, which unwillingly raises doubts. Since the digit (2) is often replaced by negligence (6), a major Russian archaeologist and numismatist A.K.Markov inclined to read this year as 728 . Hence at least it is certain that the name Syganak appears here as the name of the city, in which the coins of White Horde are minted. The above mentioned Mubarak-Hodge, according to "Anonym of Iskander" did not build anything, but rather "his reign was full of continuous turmoil" (Jakubowski, 1929). And it is known that at Erzene Khan (father of Mubarak-Hodge) and Urus (seventh descendant of Horde Ichena) the mosques, kanaka and other public facilities were built in Syganak, It is also relevant to mention here the comments of other medieval author, a secretary of the Uzbek Khan Shaibani and founder of the state of Sheibanids, who accompanied his master in his campaigns, Fazlallah ibn Ruzbihana Isfahan, describes the city of Syganak, in his book "Notes of Bukhara guest": "Possession Sygnak - the end of landscaped land of the north part of Dasht. In the old days it was very large and flourishing city. This whole area is very improved and cultivated, and all that contributions were due to all kinds of good mind. This city is really a frontier outpost of Dasht-i-Kipchak and is famous throughout the world with its extensive areas and the presence of security as well as tranquility. From trustworthy people of the country, it became known that in earlier times, and earlier ages in this well-ordered possession and abundant joys there were so many people and the inhabitants, that every day in the markets five hundred camels were roasted, and in the evening at the markets there was no any piece to eat. Truly, this land is capable to undergo such an accomplishment. Irrigation channels of cultivated fields are all put out Seyhun River (the ancient name of the river Syrdarya). Steppes and fields of this land are rich in water, grass, shrubs for fuel. In the steppes of that ownership, as herds of sheep in the pastures, the wild antelopes, kulans, desert bighorn sheep (animals living on the territory of Kazakhstan), and various other animals, are grazing off. All people living in the possession in non-winter days are much hunting and making food supply for winter. Meat of animals caught in hunting, in possession area is cheap and costs a little. Ruzbihan in his book describes in details the trade relations of the city and assortment of the products come into the market of the city: "In this country from Dasht, from Haji-Tarkhan (medieval city of Golden Horde, which was located at the mouth of the Volga River. The town was first documentarily mentioned by Arabian traveler Mohammed Ibn Battuta in 1333 under the name of Haji-Tarkhan) many benefits, fat sheep, horses, camels are delivered as well as other valuable products, such as fur coats made of Kish and Tina, that is, sable and whites, taut bows, arrows of white birch, silk and other precious items. Since [Sygnak] is the beginning of the livability of the center of ownership with respect to the inhabitants of Dasht. Thus the merchants of possessions and area of Dasht-i-Kipchak to the limits of the river Adil, which are the northern parts of landscaped area [lands], and adjacent to the coast of the Bahr al-Muhith (the ancient name of Caspian Sea) made the city Sygnak a place of storage of their goods and bring here trade goods. Merchants from the regions of Turkestan, Maury and the East up to the limits of Kashgar, Khotan (medieval town located on the territory of the modern People's Republic of China) bring to Sygnak products of these countries and make the trade deals and exchange with people of Dasht. Since these trade deals are done in Sygnak, this possession is a permanent place of merchants from [different] countries, and the good and goods of all countries are in abundance over there" (Ruzbihan, 1976).

Summarizing the information acquired from written sources, one can say that Syganak located in a settled agricultural oasis on the lower flow of the Syr Darya, more developed in the pre-Mongol period, starting from XIV century Syganak became a major political and economical center, in which the coins were minted. In this respect equally important role had the fact that the most important trade route from Europe to Central Asia and further to the East passed through areas pre-Syr Darya regions, where, due to this fact, there is renewal of 
economic life, establishment of economic relations with the pastoral areas, which in its turn stimulated the expansion and development of nomadic economy as well. This situation had also great influence on the revival of Syganak, located in close proximity to the nomadic population of Dasht-i-Kipchak, on the outskirts of Turkestan, where settled farms were flourishing.

\subsection{Archaeological Research of Syganak}

Without proceeding to the question of archaeological study we will focus on the name of the city. In written sources the name of the town sounds differently. Based on this information the scientist S. Zh. Zholdasbaev wrote in his book titled "In the history of irrigation of Turkestan" and points to a different pronunciation of the name of a medieval settlement: "At present, there are the ruins of the fortress Sunak-kurgan on the pronunciation of the current Kyrgyz (Kazakh), the name of the city was Saganak; the spelling of medieval manuscripts and even more recent official documents point to a different pronunciation - Sygnak, Sugnak or Suganak, and linguistically it also would be difficult to explain the formation of such a form as Sunako (the modern name of the fortress), from Saganak (Barthold, 1965). However, since the issue cannot be solved yet, we still maintain this pronunciation adopted in most of the articles about the ruins on the Syr Darya and the current researchers of the settlement support this view and called the settlement as Syganak. Russian researchers noticed the city Syganak in second half of XIX century. In 1867, on the instructions of Russian Archeological Commission P.I. Lerh visited this place and left the information about location of the city.

In 1884, N.I. Veselovsky went on his first trip to Central Asia. He started his archaeological field work exactly in Turkestan, where he was sent from 15 November 1884 up to November 15 of 1885 . Till that time it was thought that V.A. Kallaur and I.A. Kastane made the first archaeological excavations in medieval towns. But archaeologist M. Kozha in his article "N.I. Veselovsky on the antiquities of southern Kazakhstan, "said that" research of N.I. Veselovsky changes the understanding of the history of archaeological study of the monuments of the Lower and Middle Syrdarya. However, so far, the results of his studies on the settlements of lower and middle flows of the Syr Darya remained unpublished and therefore became unknown to archaeologists" (M.Kozha, 2008). The manuscript of N.N.Veselovskogo stored in the archive under the name "Description of ruins of ancient cities on the road from Kazaly to Tashkent" consisting of 52 pages was written in the beginning of the first trip of N.I. Veselovsky to Central Asia, which began on November 15, 1884. In his work a description of the medieval cities of Kazakhstan as Dzhankenta, Sygnak, Sauran, Mirtobe, Turkestan, Otrar, Sairam is given (Veselovsky, 1884). Researcher not only described and fixed the occurrence of the monuments, made copies of inscriptions, drawings and plans of settlements, separate parts of architectural monuments, but also led the excavations of separate sections of the settlements.

Ethnographer E.A.Smirnov, conducting reconnaissance missions from Tashkent to Kyzylorda (now the city is the center of the area in which the medieval Syganak is located) in 1892, visited Syganak, gave an information about the irrigation system of the city and its areas by irrigation ditches Tumen (irrigation canal which still retains its name), but no information about the city did not leave. In 1899, the chief of local history department V.A. Kallaur of Turkestan Ethnographical Department carried out investigation, made pictures of Syganak and topographic plan of the mosque facing the city gate at $100 \mathrm{~m}$ to the East of the city.

In 1906, archaeologist I.A.Kastane has visited the city Syganak to complement data of Kallaur (Eleuov \& Bakhtybayev, 2011). In 1927, based on the task given by the Institute of Material Culture at the Russian Academy of Sciences A.Yu.Yakubovsky visited the city of Syganak. Further he studied the city, photographed it and wrote a great scientific article that has not lost its scientific value (Yakubovskiy, 1929).

After 20 years a director of SKAE (South Kazakhstan archaeological expedition) A.N. Bernstam visited the city. After making a plan on topology of the settlement and after collecting the surface material, he suggested that there was a settlement BC from Kangyui times. According to A.N. Bernstam, an ancient layer of the settlement is mainly covered by cultural layers of medieval ceramics of Kipchak period, i.e., ceramics of Mongol Timurid style. These layers are cut by the wedged layers from the bottom part, carrying debris of Sughd Karluk appearance. This ceramics, typical for relatively high technology and solid geometric shape of the plot of ornament, similar to ceramics of Samanids in Maurya and Karluks in the Seven Rivers, and should be referred to the Syrdarya Oguz. Study on Syganak primarily would shed light to the development of cities in South Kazakhstan at Samanids and in XI century at Karakhanids (Bernstam, 1949) (Figure 1). 


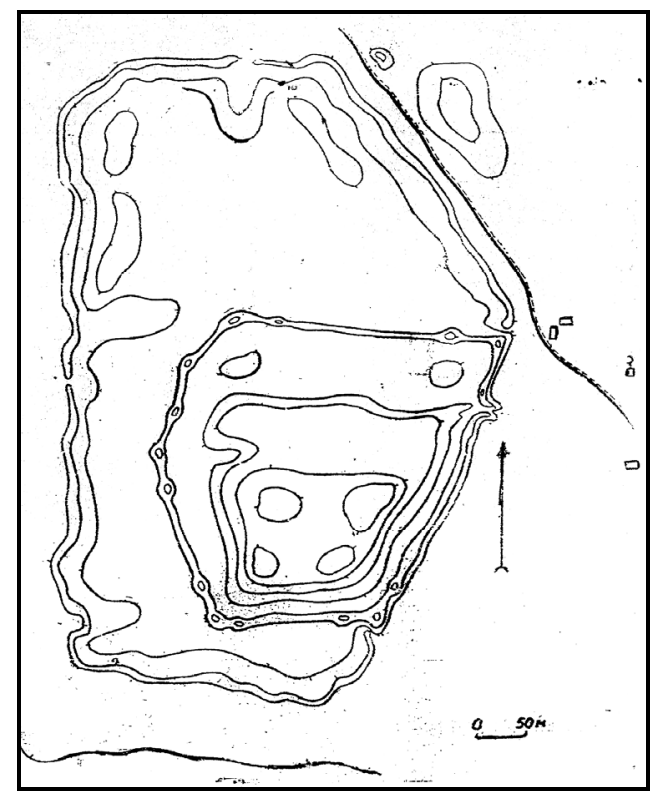

Figure 1. Topological plan of the settlement Syganak (by A.N. Bernstam)

In the late 40's and early 50's of XX century during archaeological reconnaissance the leaders of SKAE E.A.Ageeva and G.I.Patsevich have visited the settlement. According to the received material they conclude that Syganak began its life in VI-VIII centuries, then fades and flourishes again in the XV-XVI centuries during the Ak Horde Khanate. However, they also did not carry out excavation work (Ageeva \& Patsevich, 1958). In the 70-ies of XX century OAE (Otrar archaeological expedition) was organized, and was led by archaeologist K.A. Akishev, his deputy - K.M.Baypakov. They carried out investigation on Otrar oasis. Having been in Syganak, K.A. Akishev noted, that this settlement is rated to be a second after Otrar (Akishev et al., 1970).

In fact Syganak deserves such a comparison. The city resisted for 7 days the onslaught of Jochi Khan the son of Genghis Khan, while Otrar was six months against an army of Chagatai and Ugedey. From all the cities on the Syr-Darya the most affected by the Mongols was Saganak; for the murder of the Mongolian Ambassador all inhabitants of the city were killed; in the meanwhile this city was destined especially long life; since 1328 the descendants of the same Jochi Khan, who had slaughtered the population of Syganak, minted in the same city coin. Apparently, the city then again went into decline, because the recovery is attributed to its well-being of Urus Khan, the seventh descendant of the Horde-Ichena and older contemporary of Tamerlane warlord, in the second half of the XIV century, captured by its power Central Asia, Persia, Baghdad, Damascus, Egypt and India, and proclaimed himself as a ruler of the empire. Referring to the achievements of his grandfather, grandson of Urus named Barak-Khan in 1426, stated the claim to the city, so that there was a clash between them the Timurids, i.e. Ulugbek and Shahruh (Timurid rulers of Turkish power, followers of Timur). Even in the "Abdulla-name (Sharafnama and shahi)" written about the Bukhara Khan Abdolla II in 1590, Hafiz Tanyshom -Central Asian historian of Bukharian origin, says about Syganak that it "was a capital of Khans of Kipchak (i.e. Kazakh) steppes" (Bartold, 1965). The Wafk certificates show that Syganak as a city already existed in the XVII century, in the certificates several ditches, by the way, a ditch (creek) of Ordakent, such the castle ruins are still called to the south-east of Sunak-Kurgan. All above mentioned scientists didn't carry out excavation work on the settlement Syganak, they only gave a description of the state of the settlement and gave the chronology of the city by the ceramics found in the upper layers of the settlement.

In 2003, under the supervision of archaeologist S. Zh. Zholdasbaev an archaeological expedition on the site of Syganak was established. Without starting the excavation the scientists have described the ruins of the settlement. It says that the old city is located on the flat area and is clearly defined by mounds of various shapes and sizes, which are remnants of the former buildings. Currently, the entire territory of the settlement is in the thick undergrowth. According to the administrative division of Kazakhstan, the monument is located in the area Zhanakurgan of Kyzylorda region (Figure 2), in $40 \mathrm{~km}$ north-west of the district center. 


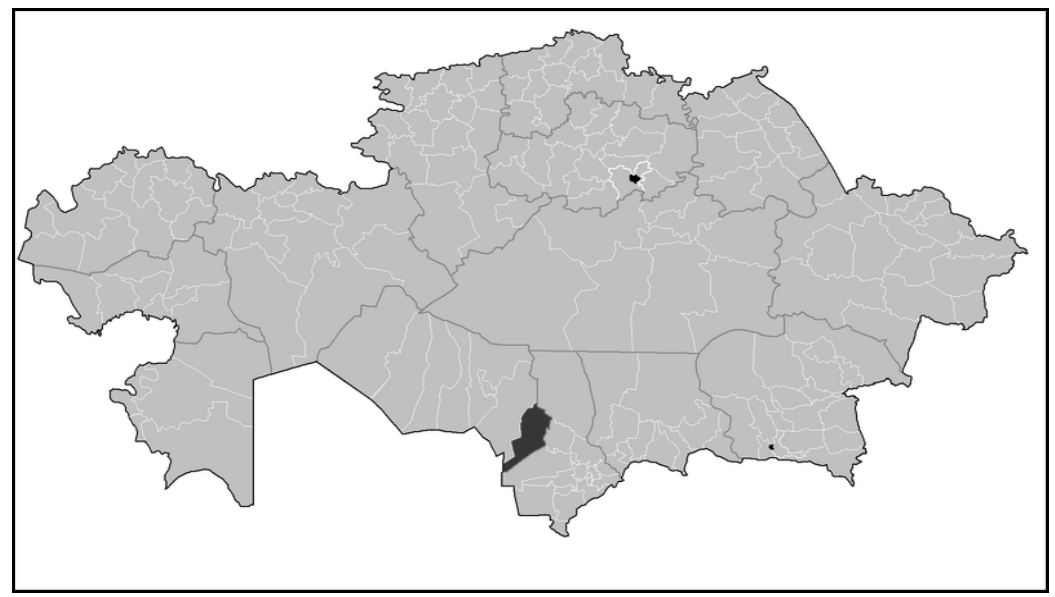

Figure 2. Location of Zhanakurgan region (where the settlement is located) on the geographical map of Kazakhstan

The medieval cities of Kazakhstan are usually composed of three parts: the citadel, which is the administrative center of the city, Shahristan, home to affluent residents of the city and Rabad, inhabited by the population of the lower social level. But this settlement Syganak consists of two parts: Shakhristan and Rabad adjacent to Shahristan on three sides.

Shahristan is located in the south-eastern part of the settlement and is represented by the ruins of a once mighty fortress in an irregular pentagonal shape with a side length: north - 275 meters north-west - 175 m, south-west $180 \mathrm{~m}$ south - $175 \mathrm{~m}$ south East $320 \mathrm{~m}$ (Fig. 3). Entrance to the fort is located in the north end of the south-east shaft and is 20-meter long with corridor like passage. Preserved shaft height is of 6-7 m, but judging by shape, the original height has reached up to 10-12 m. A shaft perimeter was reinforced by 15 towers, the remains of which still dominate the shaft up to $1 \mathrm{~m}$. The internal part of Shakhristan is almost on entire depth is filled by cultural stratum. In the whole area of Shakhristan one can find a large number of surface materials in the form of brick, unglazed and glazed ceramics, mainly, late medieval period.

On three sides, except the south-east, adjacent to Shahristan is Rabad. Most of its length is 650 meters and width of $250-400 \mathrm{~m}$. Rabad is surrounded by earthen wall, preserved to the present time, height $0.7-1.5 \mathrm{~m}$. It's the most built-up part is the area of the west and the north. In these places the largest number of mounds of various shapes and sizes were remained - the remnants of medieval buildings.

As in Shahristani whole burnt bricks, and their fragments, unglazed and glazed ceramics are met throughout Rabad area (Figure 3).

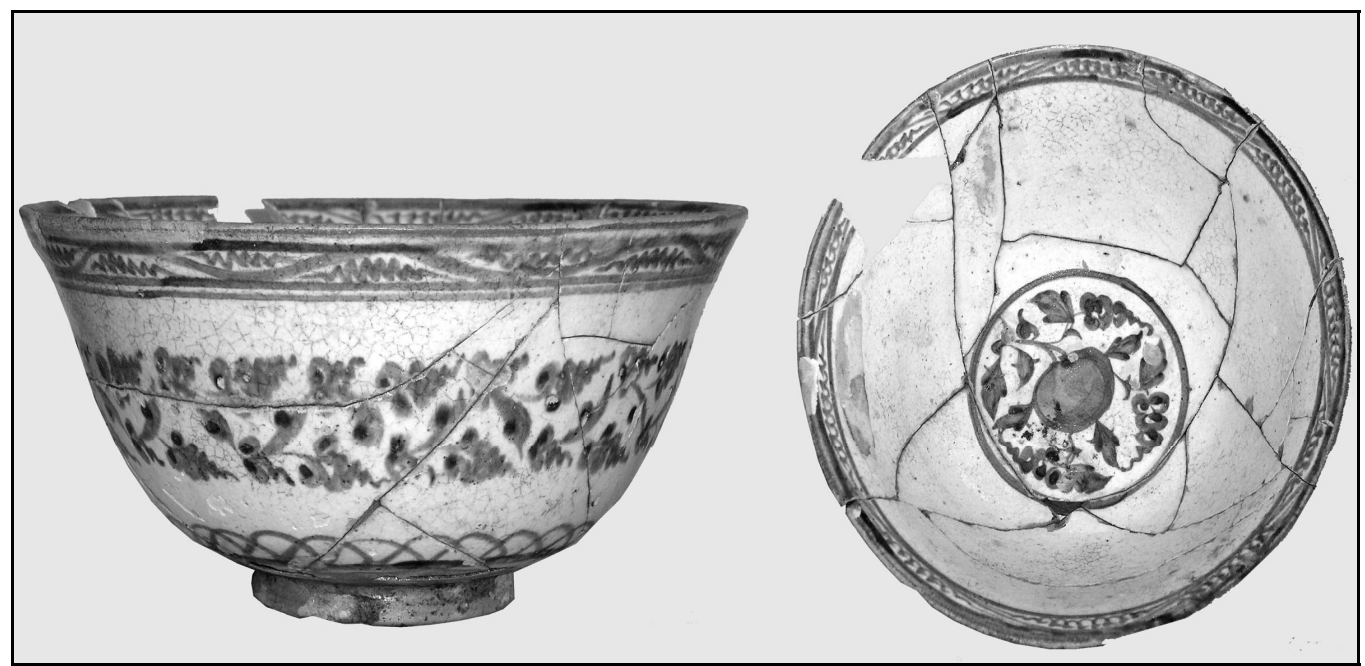

Figure 3. Glazed ceramics 
During the excavation work a mosque-saga was discovered (crypt) (Figure 4).

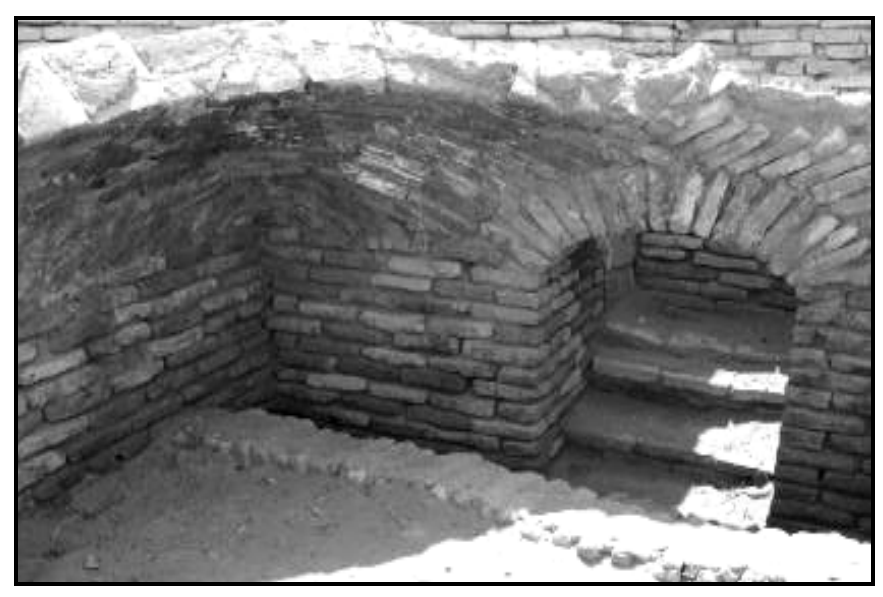

Figure 4. Mosque saga (cellar)

And the members of the expedition suggest, that it has found a second life after repair and turned into a mosque and madrasah (structure that can perform two functions simultaneously: first, it is the home, where Muslims are committed to serve God, and second, the religious school where they teach the alphabet and reading, science, Muslim holy book the Koran). These mosques, madrassas, according to sources, have been built in the XI century.

Archaeologists puzzled question what is the function performed this building in fact, discovered during the excavation. And comparing the mosque and madrassa opened in other medieval cities, the archeologists have come to the opinion that this room is actually a Mosque-Madrassa. Archaeologists have implied such thought because around the prayer hall and Sagan (vault) seven small rooms were built. Such buildings were discovered by archaeologists in 1973 during excavations at medieval site Otrar. Such construction began all around after the construction on the orders of Timur (Tamerlane ruler) - the mausoleum in honor of the great educator $\mathrm{H}$. A. Yasaui, lived in XII century. There was no doubt about it.

According to the data from archeologists those building performed 4 functions:

1) rooms for prayers;

2) premises for studying Koran (ancient book of Islam religion);

3) library to preserve Koran and other religious books;

4) room for a petition to God for the remission of their sins.

The largest room $(9,8 \times 9,8 \mathrm{~m})$ is prayer room.

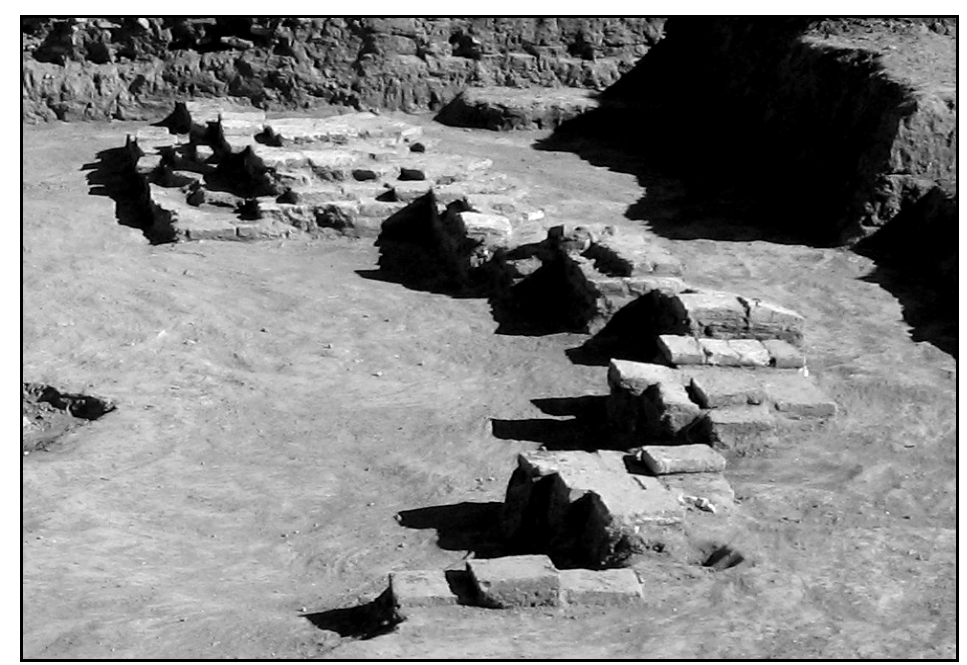

Figure 5. Traces of Mihrab 
Mihrab (Figure 5). (opening in the western wall of the prayer hall of the mosque, where one can tilt the head, turn to God of Muslims) is situated at the southern wall of the center. It corresponds to the Mihrab of H.A. Yasaui. Room, after the Mihrab on the south side of the wall, is particularly decorated in compare to other rooms The walls are plastered with a red alabaster. The solution is well preserved. On the south wall remained a rhomb, painted in blue and white color. This rhomb regarding its color is exactly like the rhomb in the prayer hall, in the mausoleum of H.A. Yasaui. This is evidenced by the construction at the end of XVIII - early XIX century on the banks of the Syr Darya (Zholdasbaev, 2010). Archaeological research in the region, on the area of 100-150 km showed, that mosque-madrassas were opened in every medieval town. During excavation works under number 9 the Eastern gate, considered the main entrance to the fort, and was recorded. At this time, the height of the walls of preserved gate, from north to south is gradually reduced to two meters. After making the topographic plan of the Eastern gate territory the clearly visible differences from the other door of the medieval city were observed. If the design of the towers and gates of Otrar and Sauran are slightly extended from the platform, and during the excavations, at the gates, the racks for hanging bridges were found. In the settlement of Syganak the main platform was built of baked bricks, the towers on the sides are made of rammed clay construction (Figure 6).

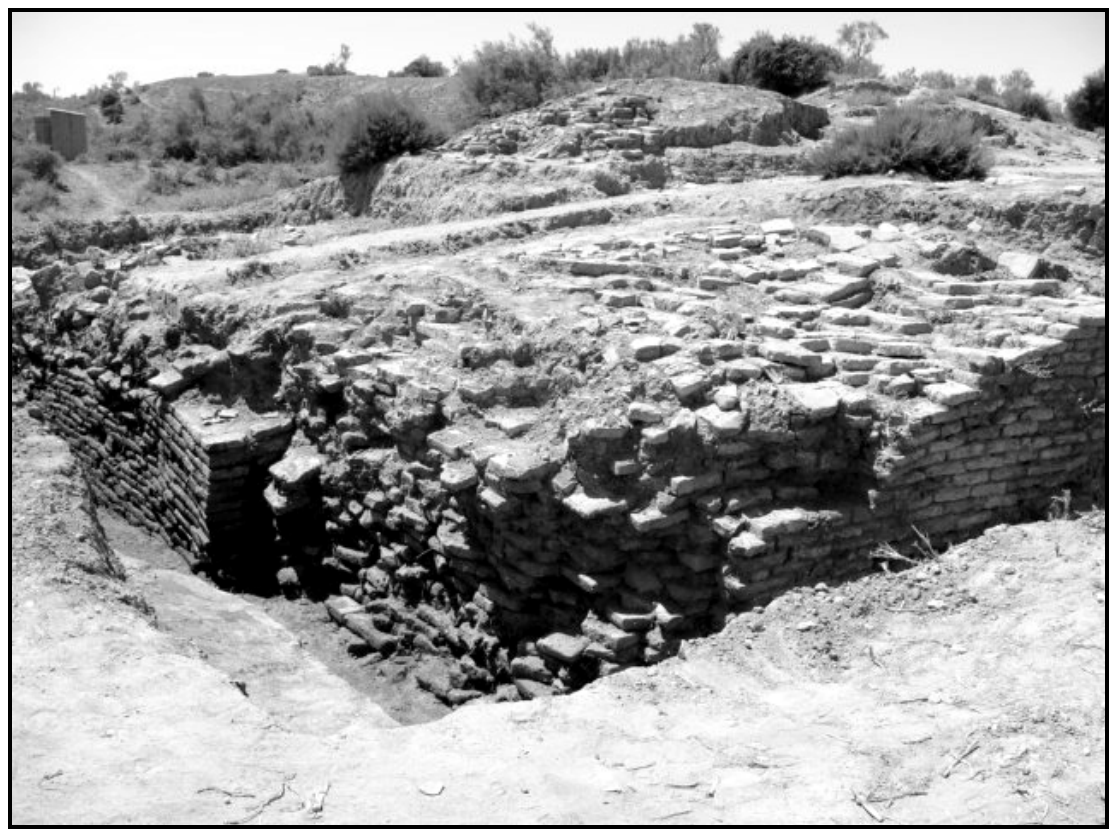

Figure 6. Main platform of the gate. View from the Northern corner

The main platform is extended forward by 4.5 meters. Preserved height of the platform is 1.7 meters. The remarkable issue is that in the architecture of the gate at that moment in front of the gate the vertical supports for hanging bridge were not found as observed in other cities. However, work in this area is not finished.

Archaeological excavations on the settlement have not been completed and excavations are carried out in the upper layers of the settlement. But archaeologists believe that they will find all scientific facts indicating that the city was in its time, as stated in the written sources "harbor of Deshti Kipchak".

\section{Conclusion}

Historical and cultural significance of Syganak is defined by the following reasons. The first is that Syganak and surrounding regions were ancient center of settlement, of irrigated agriculture and urban civilization of Kazakhstan. These medieval buildings, which we discussed earlier, found during excavations on the site of ancient settlement with a dome ceiling, built of mud bricks, indicates, that population of southern Kazakhstan possessed not only the technique of manufacturing raw brick, but also constructed cult buildings of complex structure, had building expertise. Undoubtedly, the experience and skills have been acquired as a result of the construction of residential and commercial buildings, and architectural design of the whole city.

Now we can say, looking at the settlement, that the evolution of the medieval city is established by genetic continuity from the early Middle Ages, before the development of the city. Of course, this way of development was only possible through the origin of the medieval city. But this conclusion has fundamental importance for 
the study of the genesis of the city and the establishment of tradition and innovation in its culture.

During the development of medieval the southern Kazakhstan, including Syganak, is becoming one of the largest centers of urban civilization in Kazakhstan and Central Asia. The scale of the economic and cultural development of the oasis is described by the settlement ruins, traces of a powerful and widely ramified irrigation system.

Second, Syganak is a major center on the Silk Road, the meeting center of different cultures and civilizations: Chinese, European, Oriental, religions - Christian, Muslim. Syganak was not only a center of economic and cultural life, but also a center of scientific thought of medieval Kazakhstan. Syganak culture has influenced the live of the entire Syrdarya region. The subsequent formation of the Kazakh state was closely associated with the spread of Islam. The significance of the cultural life of the region is in its role in strengthening the position of Islam in the construction of mosques and madrassas. A great contribution to the spread of Islam among the nomadic Turkic peoples of southern Kazakhstan has been done by the ones come from the city; these are Shaykh Baba Syganak, Husam al-Din al-Hussein al-Syganak. The history of the name of a historic settelement Sunako or Syganak and religious activities Sunako-Ata and his descendants require a separate special study. In the XIV century, Kipchak poets Qutb and Berke Fakih Kipchaks (the tribes living on the territory of Kazakhstan) came from this city. Qutb wrote his poem "Hosrau - Shyryn" in this city. This work is devoted to Ak Orda Tynybekov Khan and his wife Malika Khatun. One copy of the poem Berke Fakih took to Egypt (1383), where he rewrote it at the request of his relative Kutkozhy. Currently this manuscript is kept in the National Library of Paris under number 312 .

The third reason - the geographical location of Syganak between agricultural oases of Central Asia and nomadic cattle area of Dasht-i-Kipchak. Especially in this area, as nowhere else, since ancient times there were infiltration of tribes, mixing, and the mutual influence of cultures. If the origin of the sedentary life and farming culture, the emergence of fortified settlements began in the tenth century of AD, then its improved development began from X-XVIII centuries. As a result, in southern Kazakhstan kind of urban civilization has been developed, where clearly singled beds and original elements of the former culture are extracted.

Fourth, the importance of Syganak is determined by "Kipchak problem", that the city was the capital of the Kipchak Khanate, it is proved by the culture of Kipchak tribes - the main inhabitants of the vast steppes of Dasht-i-Kipchak. The great role played the ancient Kipchaks in the development of the Kazakh people, their material culture, language, and in the formation of the state - the Kazakh Khanate, that is, the medieval prototype of modern Kazakhstan. Settling of Kipchaks, spread of their culture can be also traced through the study of Syganak and other cities of Syrdarya area.

From ancient time the Southern Kazakhstan, the lower and middle flows of the Syr Darya and Syganak were wintering area for many pastoral tribes, and later for the most Kazakh clans and tribes. It also has determined that this is a place where the process of consolidating of numerous tribes of Kazakhstan into one nation has started and finished. Southern Kazakhstan is the cradle of the Kazakh people.

Fifth, the importance of the medieval Syganak is defined around key questions and without learning cannot be solved the problem of the genesis of the material and spiritual culture. This is the theme of human settlement in the territory of Kazakhstan as well as evolution of its culture. Sixth, Syganak is a center of Ancient statehood.

The concept of "proper medieval archeology" begins from VI-VIII centuries, i.e., the so-called the ancient Turkic time, which in science is called as the early Middle Ages. The highest stage of cultural development of ancient Turkic tribes of the East was the state of Karakhanids (940-1141 years).

Currently, one can only imagine what level of social development would reach Karahanid state if its process is not interrupted by the invasion of the Mongols. Mongol invasion inhibited not only the development of the state, but, more importantly, the process of consolidation of the Turkic tribes into one nation.

Seventh, the significance of Syganak is explained by the fact that it is here as a unique heritage of the economy and agriculture, remains of ancient irrigation were preserved and studied - channels, distributors, dams, remnants of fields, orchards, melons. Their studying allowed establishing the dynamics of oasis irrigation from the early to the late Middle Ages.

\section{References}

Ageeva, E. I., \& Pacevich, G. I. (1958). From the history of settlements and cities of Southern Kazakhstan. Work at Research Institute at the Academi of Sciences of Kaz SSR. Almati.

Ahinzhanov, S. M. (1989). Kipchakcs in the history of medieval Kazakhstan. Almati. 
Akishev, K. A., Baipakov, K. M., \& Erzakovich, L. B. (1970). Ancient Otrar. Almati: Science.

Barhold, B. B. (1963). History of cultural life of Turkestan. Turkestan and Turks. Collection of compositions, 2.

Barthold, B. B. (1965). To the history of irrigation in Turkestan. Collection of compositions, 2.

Bernstam, A. N. (1949). Problems of ancient history and ethnogenesis of the Southern Kazakhstan. News of Academy of Sciences of Kaz SSR. Archeological serie (Vol. 2, pp. 68-139). Almati.

Burnasheva, R. Z. (2006). Monetary circulation in the cities of Southern Kazakhstan in XV-XVIII centuries. Turkestan.

Eleuov, M., \& Bahtibaev, M. M. (2011). Protocols of minutes and messages of the Members of archeological $c l u b$. Historical and cultural Monuments of Kazakhstan. Turkestan: Turan.

Gandzaketsi, K. (1976). History of Armenia (translation from ancient Armenian, preface and comment by L. A. Hanlaryan). Moscow.

Isfagani, F. R. (1976). Mihman-name-yi Bukhara (Notes of Bukharian guest) (translation of R. P. Jalilova). Moscow: Science.

Kashkari, M. (1997). Dictionary of Turkic language. Almati: Hant.

Kozha, M. B. (2008). N. I. Veselovskiy about antiquitiesof Southern Kazakhstan. Vestnik Internationa Institute of research in Central Asia (Vol. 8, pp. 3-13). Samarkand (Uzbekistan).

Mingulov, N. N. (1981). Some questions on studying of history of Ak-Horde (Kazahkstan in the epoch of feudalism). Almati.

Petrushevskiy, I. P. (1977). Campaign of the Mongolian armies to Central Asia in 1219-1224 cc. and its consequences. Tataro Mongols in Asia and Europe.

Pishchulina, A. K. (1969). Pre-Syrdarya cities and their role in the history of Kazakh Khanates in XVI-XVIII centuries. Kazakhstan in XVI-XVIII centuries (Questions on social and political history). Almati

Veselovskiy, N. I. (1884). Description of the ruins of ancient cities along the road from Kazali to Tashkent. Manuscript. Foundation No. 111. Description No. 1.

Yakubovskiy, A. Y. (1929). Ruins of Syganak (Sugnak). Message from GAIMK (Vol. 2, pp. 123-159).

Yudin, V. P. (1992). Hordes: White, Blue, Gray, Gold ... Utemish-Hadji. Chingiz-name. Almati: Gilim.

Zholdasbaev, S. Z. (2010). The medival city Syganak (XVI-XVIII centuries). Turkestan: Turan. 